\title{
Daring Deeds: Translation as Lesbian Feminist Language Act
}

Marlene Wildeman

\begin{abstract}
Traductrice de La lettre aérienne de Nicole Brossard, Marlène Wildeman s'adresse ici aux éléments morphologiques et intégrales de sa traduction, tout en soulevant quelque questions théoriques vis-à-vis les notions traditionnelles de la pratique de la traduction. Entre l'écriture de Nicole Brossard et la lectrice de ces textes en anglais se tend la corde littéraire de cette funambuliste féministe et lesbienne qui, osant pratiquer son art - son combat - dans l'inédite féminine, s'avance et nous avance dans le plaisir inoui du texte sans filet.
\end{abstract}

La Lettre aérienne, published in the Fall of 1985 by Montreal's Editions du Remue-ménage, brought together a decade of Nicole Brossard's essays, lectures, and texts on writing with fragments of poetry interspersed. Recognizing at once the effect this book would have on lesbians and women who write, I immediately began to jot down English words in its margins. What exhilarated me was how the book dealt with something I have felt as a writer myself: the false dichotomy of wanting to write fiction yet needing to be active politically as a lesbian feminist. Choosing one always seemed to mean, in practical terms, abandoning the other. Then here was Brossard's Lettre, daring to speak to all feminists from within lesbian difference, and it clicked into place as lesbian feminist theory and practice of writing. I became possessed by the book as only a translator can be: I had to make this writing desire available to the English feminist readership. I had to relay not only the Brossardian vision of lesbians and women writing but a sense of the literary preoccupations of Quebec feminists in general, which I knew was still a mystery for the majority of Canadian feminists. I realized the blueprint of my target readership, an important factor in the translation process, was beginning to take form. It was particularly important in this translation, since I was not translating for the post-structuralists who would likely read Brossard in the 
original, but for all English-speaking lesbians and feminists who were tempted to explore the fiction theory of Nicole Brossard. Re-located in Brossardian text, yet grounded in my English Canadian lesbian feminist desire to write / act, I began to assume the third dimension of translation: the projection onto my readership of a fictive recipient consciousness, from which I took direction and was able to chart my bearings.

\section{Desire Translates}

'... what is obstructed here is desiring, and desire writes ...'

The equilibrium needed to survive this non-renunciation is found in the solitary intimate act of writing. ${ }^{2}$

On the first page of this first text in Brossard's Letter, we find the key to disrupting the hegemony of patriarchal language: desire writes. In translating this desire, not only female but lesbian, there lay in store a particularly challenging double-dare, for behind the front 'woman' were '... two modes of existence which inscribe themselves in the margins of the normal-normative course of language and the imaginary and, consequently, in the margins of reality and fiction. ${ }^{3}$ I had to ensure that the implicit doubling of the writer who is not only woman but lesbian find itself in the mirror of its mirror on the reflected English page. And in this, remain faithful to Brossard's vision of l'intègrales, a singular collective, women and lesbians together in feminism, cracking codes that hold us all powerless, learning how to '... inscribe one's perception and one's vision of the world in language ... in response to an inner necessity ...' becoming '... a subject in (the) process, moving, changing, a being in pursuit of.' ${ }^{4}$ I wanted to make The Aerial Letter, like the original, a textual site for self-generating lesbian feminist praxis in language. To make the process '... a revolution around its axis: ... (examining) the root from all angles, from every point of view, ${ }^{5}$ I proceeded then with '... lines written in a feverish but nonetheless precise hand, ${ }^{6}$ to write this desire in translation, inscribing this textual body in otherwords, certain words which, in their relation to every other word, constitute a book-length political act of language, and in particular, a lesbian feminist language act.

Perhaps the greatest translation challenge arose from the fact that The Aerial Letter re-creates, poetically, lesbian feminist consciousness 
in a (patriarchal) language foreign to it. And this within a critical tradition where success is measured by the degree to which the reader remains formally unaware of this étrangeté. Translation as balancing act, drawing upon extremes of resemblance and difference, not only makes the foreign language familiar but, in this instance, couches the embedded lesbian phrase in the greater feminist textual framework, working toward a complicitous reader response. For in The Letter my task as translator was not only to wield differences in language / thought / emotion / culture, speechways of thinking / being / seeing, bringing them to a just equivalence on the English page, but through language to engage the reader to the point where '... inclined to become one with the text in order to seize in the fire of the action the brilliant exploit of ... (her) desire ...,' she is '... astonished before the unanimity forming within $u^{\prime}:^{7}$ author/translator/ reader.

\section{Translation as a Feminist Act of Language}

Feminism can be defined as an intense loyalty to that which is believed to be supremely worthful in women's lives, and a vivid sense of cooperation with the forces that are working for its realization. ${ }^{8}$ Although it is acknowledged that lesbians are women who are different from women as the term is commonly understood, for our purposes here let us assume that lesbians are included in this definition of feminism, and consider that in word and deed, for both lesbians and women, cooperating actively with the forces working to actualize women's and lesbians' writing desire constitutes the feminist act.

Feminist translation then falls into two main categories:

1) the righting of a text which, in the original, had been negligent with regard to women and lesbians, and

2) the writing or re-inscription of a text originally conceived within the feminism and / or lesbianism of another language and culture.

In The Aerial Letter I was going from Nicole Brossard's readingand-writing French feminist thought in Quebec, concentrated on language itself and why women write, to morphologically genderless experience-and-identity English. Initially, English as re-inscription will disappoint the feminist strategies of a French text. Through the deliberate use of both the masculine and the feminine pronoun, Brossard had invested her text with a particular female presence ${ }^{9}$ which, without feminist translator authority, would have been eclipsed in English. Watch how the bold gendered French pronouns become an 
all-purpose 'Those' in the following fragments, and how I subsequently re-claim that demonstrative for the female subject:

Ici, un question: le texte comme papier d'identité ou l'identité comme une science-fiction de soi dans la pratique du texte? Car celui ou celle qui n'a jamais pu parler la réalité de ses perceptions, celui ou celle à qui l'on empêche politiquement et patriarcalement la conquête de son propre territoire émotionnel, celui-là, celle-là saisira que l'identité est à la fois quête et conquête du sens. Lente émergence du désir dans l'inavouable de son projet de transformation de soi et de la collectivité. Inavouable volonté de changer la vie, de changer sa vie. ${ }^{10}$

Here, a question: the text as I.D. card or identity as a science fiction of self in the practice of creating text? Those who have never been able to speak the reality of their perceptions, those for whom the conquest of personal emotional territory has been precluded politically and patriarchally, will grasp that identity is simultaneously a quest for and conquest of meaning. Desire slowly emanates from what is inadmissable in her project: transformation of the self, and the collectivity. Inadmissible will to change life, to change her life. ${ }^{11}$

As the following example will show, French can be more intimate, nurturing complicity among women. On morphological bases alone, it is closer to the point of utterance, its female infixions irrevocably firm. ${ }^{12}$

Les belles musclées dans l'herbe, heureuses et acharnées ont vu leurs poils briller de mille adresses quand la mémoire leur vint que des surfaces, au fond, naissent la conscience de l'espace (avec elles). ${ }^{13}$

Here a straight English translation would have been the beautiful muscular ones, but male ones or female ones? In English, unless they refers anaphorically to a specifically female subject, it remains (neutered) male unless stipula ted Other-wise. Forced to identify the feminine subject, we attach the word 'women,' but in doing so we forfeit our independence. At degree zero, we are contingent, other, and not the thing itself:

Beautiful muscular women in the grass, happy and ferocious, saw their body hair glisten with a thousand scintillae when the memory came to them that surfaces, deep down, gave birth to the consciousness of space (with them). ${ }^{14}$ 
An isolated example, however, does not convey the sensation of dropping out of the French feminist text into English neuter forms. It might be comparable to making the change from a women-only environment to a world where one encounters men; the difference, where not striking, is nevertheless perceptible.

\section{La traduction engagée}

Nicole Brossard calls this la traduction engagée: feminist translator involvement in the source text resulting in a re-inscription informed by feminist consciousness. If non-feminist translation has traditionally prided itself on objective indifference, feminist translation conscientiously moves to the fore active recognition of resemblance within subjective difference, as strategy for cultivating feminist consciousness through the written word.

Feminist strategies in The Aerial Letter are two-fold: those related to the content of the translation as a whole, that is, the meaning transmitted holistically, and those related to matters of feminist morphology, pronoun shift (mentioned above), mirroring feminist cultural reconnaissance symbola, re-creating textual spiralling, webbing, fragmentation, etc.

With respect to the first fold, I wanted the English reader to come away from her reading of The Letter with a sense of rejuvenated joy in feminist reading and writing, one that would parallel that experienced by the French reader. In a few places where a strict translation would have been at best dutiful, and where there was feminist justification for the deed, I deliberately introduced author-approved target text departures. Ethically and aesthetically, feminist theoretical texts seem particularly disposed to accept feminist language acts of this nature: we want to create a final product which corresponds to the author's original intention, we do not want women's reading desire to falter before literary obstacles, and we do want to see evidence in the translated text of mobile female forms nourishing renewed inspiration for actively feminist reading and writing.

\section{L'écriture de dérive, feminine / féminin, and feminist sensibility}

There are two translation issues I would like to mention in the context of decisions affecting the whole book: 1)l'écriture de dérive, and 2)the matter of feminine / female, where 'feminine' tends to be pejorative in 
English while 'féminin' is viable in French, possibly due to its indisputable morphological existence in that gendered language.

L'écriture de dérive signifies writing which has been shunted off from patriarchal ideology. Of note, the French noun dérive connotes the deviation implied therein, as well as the calculable drift or distance produced by such differentiation; whence phenomena such as 'lesbian feminist literary criticism.' However, although 'derive' and 'derived from' are English language words and concepts, and although the present day use of the verb 'to derive,' in both French and English, is derived from mixed French and English origins, the French noun dérive is represented in English by 'derivation' or 'derivement,' neither of which spontaneously conveys a writing and / or desirearising from or originating in those women who have been de-rived, as in having been given no space but in the margins, or who have de-rived themselves, having decided that the only way to retain a sense of integrity in the face of relentless patriarchal intellectual, physical and sexual control, is to take oneself off to the side, or out of the main stream. ${ }^{15}$ Other French writers on writing, in particular, Roland Barthes, were well-served by a translation that emphasized the detachment implied in dérive, but here 'adrift' would not reflect the feminist act of consciously taking oneself and one's thinking / writing realm away from the forces that effectively deny, invalidate, or undermine it. In short, l'écriture de dérive could not appear random, or unintentional, specifically because women, through feminism, have altered the purpose of writing. ${ }^{16}$ Hence my introduction of 'elusive' writing and desire, in the sense of having slipped out from under, or having 'eluded,' patriarchal domination by moving / thinking / writing / acting outside it. ${ }^{17}$

In addition, English 'feminine' was contentious. In the first place, feminine and masculine gender in French grammar is essential to an understanding of l'écriture au féminin and différence, and it provides a basic grammatical point of origin for what we English-speaking feminists have come to call, after the French, 'writing the body.' In effect, writing the body means writing one's femaleness, making sense of the world, and words, in experiencing reality as a female, this being understood as intrinsically inédite, that is, different from what has been written before, since only yesterday women were obliged to subject their writing to masculinist literary standards. Meanwhile, believing that we have now created this new and different realm of 
female writing energy and exchange is sans doute a feminist act of faith in our own imagination.

Feminine/feminist/female/lesbian/woman. In translating Nicole Brossard's Lettre, I had to take into account the following: Nicole differentiates between a feminine and a lesbian body. If the body is writing, and it is, then each of these two will produce a different text. But if this text is being written in English, either of these two bodies writing will be described as female and both of them might be feminine. Ainsi leur text? Gertrude Stein wrote that 'Analysis is a womanly word'; Nicole had translated this as un mot féminin. ${ }^{18}$ Une analyse, of course. A French feminist re-claimer. However, 'analysis' in English, alongside 'rational,' 'logical,' and 'scientific,' fairly pulsates with masculinist territorialism. To be sure, I did not re-translate; I quoted Stein directly, as is only proper. Whether Stein's 'womanly word' means in my English translation what it meant for Brossard as un mot féminin, is a matter of interpretation: to each her own. To a certain extent, it is the case that the reader of The Aerial Letter will be her own interpreter, and I will leave to an adventurous literary critic the task of evaluating the success of my having translated féminin into its various callings in English. I can however attest to the following: I kept 'feminitudes,' because I found it fecund with female modal properties, I employed the term 'female culture' for uneculture au féminin, and not once did I allow féminin to appear in English as 'feminine,' if I thought it would evoke that collection of self-effacing powerless attributes women have been taught to cultivate as earmarks of their real womanhood.

In sum then, there were feminist equivalence decisions made with respect to consistency, where the 'feminist imaginary' of the whole collection was to be as handsomely recreated in English as it had been exquisitely articulated in French. But there was another kind of equivalence I dealt with, the second fold, related to linguistically identifiable passages where words or combinations of words bear the marks of a feminist writer at work with language tools, because she is a woman attentive to the same difference of her reader, '... an / other woman with ... (her) regard. ${ }^{19}$ And she does not have at her disposal that powerful feminist punctuator, the ellipted French '-e.'

French-speaking feminists writing virtually take over textual sites previously reserved for men only. While in English we may dare to reappropriate traditionally masculine words - try writing 'a virile 
woman' 20 without incurring 'manly' or 'butch' - there seems to remain an aura of doubt about whether we can actually get away with this. It is a dare then, and not a fait accompli; an attempted transgression which may very well be contested, whereas when we read Nicole's feminized ma continente, it is visibly a change that has been effected in the root, fixed-in, an accomplished transgression, not just a 'trying to go against.' Change on morphological grounds seems to establish an incontestible legitimacy, a kind of Common Law of Word. And certainly when, as can be the case in French, these are not isolated changes, but connected landmarks, linked one to the other by a field of related resilient adjectival agreements, the woman reading French feels welcomed into her own textual territory. ${ }^{21}$

Adroit use of 'she' and 'her' in English though will snap the unaccustomed reader to attention, re-investing the text with feminist sensibility, and setting its surface on edge. By the same stroke, we obvert the patriarchal proposition and create the breach through which, in our feminist dis / ordering, ${ }^{22}$ we dare to think, act, and re-enact from a new perspective, re / ordering reality in words that accommodate us as subject. It is conceivable then that we cut a path for the inscription, or the translated re / inscription of our realities.

When one cannot, however, invest a word with female subjectivity or feminist sensibility, in translation you may have to make a 'creative departure.' Examples of my creative departures follow:

In the firstinstance,

... nos corps rayonnants et tridimensionnels, portées vives comme de fluorescentes citées dans la nuit patriarcale. ${ }^{23}$

becomes

... our three-dimensional and radiant bodies, carried resplendent through the patriarchal night like fluorescent cities of visionary learned women. ${ }^{24}$

Here extrapolation lights the way for an empowering metaphor in English: "The light is coherent.' ${ }^{25}$

In the second instance, 'mourriture,' as it happened, had more to say in English:

... la totalité jouissive de tous ces fragments désirants. La mourriture. ${ }^{26}$

became 
... the ecstatic totality of all these desiring fragments. Euphoriture. ${ }^{27}$

with 'euphoriture' rocketing into the ecstasy of the text, uniting in one word all desiring fragments of Brossard's vision, the textual manifestation of that vision, and the sum total of women and lesbians be / coming:

(l')integral(es).

Engagées, integralwomen diverge, all-together, from the usual meaning of words, signalling to one another en route the images that resemble us, that reassemble us, reconnaissance signs of recognition, feminists in all languages charting collective dis / placement, aspiring to and spiralling toward what's real. What we a re talking about here '... is a certain angle of vision. To get there, ... (we) had to get up and move, (write / act) in order that the opaque body of the patriarchy no longer obstruct ... (our) vision. This displacement gives rise to all the others. Displacement of sense, not to be confused with disorder of the senses. Rather, it is a matter of what engenders the senses and what arranges them, a matter of all texture called upon to concentrate itself in text. ${ }^{28}$ Text-Act. Act in language. Feminist language act. Lesbian feminist language act. Trans-Act. Desire. Re/ late words one to the other. A balancing act. Across.

\section{Notes}

1. The Aerial Letter, The Women's Press, Toronto, 1988, p. 37.

2. Ibid, p. 40 .

3. p. 133 .

4. p. 133 .

5. p. 110 .

6. p. 77 .

7. p. 156.

8. My preferred definition. Alas, the source has escaped me. Credit is due someone somewhere.

9. It was not assumed the English readership would be familiar with the necessity in Québec to stipulate 'he or she,' if one wants the feminine possibility to enter into the conscious mind of the reader. A strict translation would have sometimes resulted in an ironic distortion of Nicole Brossard's feminist language principles.

10. La Lettre aérienne, Les Editions de Remue-ménage, Montreal, 1985, p. 44.

11. The Aerial Letter, p. 67. 
12. In fictions, infixes. Partly f. L. infix, pp. stem of infigere, to fix or fasten in, imprint, impress.

13. La Lettre aérienne, p. 56.

14. The Aerial Letter, p. 78. The 'them' in parenthesis is foot-noted to read women.

15. Of interest, the Compact Edition of the OED states that 'de-rivet,' in the sense of 'remove the rivets from' is confined to specifically French usage. This is no longer the case. See page 76.

16. I did, however, use 'drift' where it was appropriate and where there would be no confusion regarding l'écriture de dérive as a conscious choice, such as in the following fragment: 'it was a fabulator problem for a woman who wanted the word woman to take its own place and be in place yet still be able to drift away in the split-second moment of composing image' (p. 101).

17. With special thanks to Lucille Nelson who suggested 'elusion.' Certainly it escapes, or eludes, those readers who prove hostile to feminism.

18. P.57 in French, p.79 in English.

19. The Aerial Letter, p. 51.

20. As in having procreative power of mind, character, literary style, etc. Power that generates, that engenders.

21. See above reference to 'Les belles musclées ...' for an example.

22. Polyvalence (eg. thinking / knowing / being), dis / lodging certain prefixes at appropriate syntactic moments, daring to post-pose prepositions for end focus, and as otherwise incorporated into this text.

23. La Lettre aérienne, p. 75.

24. The Aerial Letter, p. 94.

25. Ibid, p. 115.

26. La Lettre aérienne, p. 17.

27. The Aerial Letter, p. 42.

28. Ibid, p. 79. 